\author{
Agnieszka Jaworowicz-Rudolf*
}

\title{
ŚRODOWISKO JAKO DOBRO CHRONIONE
}

\section{Definicje normatywne środowiska i ochrony środowiska}

Prawo polskie definiuje termin ,środowisko" w art. 3 pkt 39 ustawy z dnia 27 kwietnia 2001 r. - Prawo ochrony środowiska ${ }^{1}$. Według tej definicji środowiskiem jest „ogół elementów przyrodniczych, w tym także przekształconych w wyniku działalności człowieka, a w szczególności powierzchnia ziemi, kopaliny, wody, powietrze, krajobraz, klimat oraz pozostałe elementy różnorodności biologicznej, a także wzajemne oddziaływania pomiędzy tymi elementami”. Polska definicja środowiska obejmuje elementy tożsame z elementami występującymi w dokumentach prawa europejskiego i międzynarodowego ${ }^{2}$, w sposób przykładowy wylicza poszczególne elementy środowiska, włącza do definicji wzajemne oddziaływania pomiędzy nimi, aczkolwiek, na co zwraca uwagę M. Górski ${ }^{3}$, definicja skonstruowana jest w sposób błędny logicznie, zakłada bowiem, że np. powierzchnia ziemi jest „elementem różnorodności biologicznej”. Można mieć też wątpliwości, czy sam termin „środowisko” dla określenia zespołu elementów opisanych $\mathrm{w}$ definicji nie jest jednak zbyt szeroki.

$\mathrm{W}$ art. 3 pkt 13 p.o.ś. ustawodawca zdefiniował także pojęcie „ochrona środowiska" jako podjęcie lub zaniechanie działań umożliwiające zachowanie lub przywracanie równowagi przyrodniczej. Ochrona ta powinna polegać w szczególności na:

1) racjonalnym kształtowaniu środowiska i gospodarowaniu zasobami środowiska zgodnie z zasadą zrównoważonego rozwoju;

2) przeciwdziałaniu zanieczyszczeniom;

3) przywracaniu elementów przyrodniczych do stanu właściwego.

\footnotetext{
* Dr, Katedra Prawa Administracyjnego i Nauki Administracji, Wydział Prawa i Administracji Uniwersytetu Łódzkiego.

1 Tekst jedn.: Dz. U. z 2013 r., poz. 1232 z późn. zm. Ustawa ta określana jest dalej skrótem: p.o.ś.

2 Zob. J. Ciechanowicz-McLean, Prawo i polityka ochrony środowiska, Warszawa 2009, s. 16.

${ }_{3}$ Zob.: M. Górski (red.), Prawo ochrony środowiska, Warszawa 2009, s. 28.
} 
W ochronie środowiska można zatem wyodrębnić dwa podstawowe nurty: ochronę środowiska przed zanieczyszczeniem oraz ochronę zasobów środowiska. Ochrona ta powinna uwzględniać w szczególności zasadę ogólną prawa ochrony środowiska jaką jest zasada kompleksowości ochrony ${ }^{4}$, wyartykułowaną przez ustawodawcę w art. 5 p.o.ś., zakładającą, że „ochrona jednego lub kilku elementów przyrodniczych powinna być realizowana z uwzględnieniem ochrony pozostałych elementów". Środowisko - według tej zasady - powinno być traktowane jako pewna całość, zespół powiązanych i oddziałujących na siebie wzajemnie elementów, co jak wyżej wskazano wynika już z samej jego definicji. Regulacje prawne dotyczące poszczególnych komponentów środowiska ${ }^{5}$ powinny uwzględniać relacje i zależności zachodzące między nimi, a instrumenty ochrony jednego z elementów środowiska nie mogą być realizowane kosztem innych.

\section{Ochrona środowiska jako obowiązek konstytucyjny}

Obowiązek ochrony środowiska jest obowiązkiem konstytucyjnym. Fundamentalne znaczenie odgrywa tutaj norma programowa, ogólnoustrojowa zawarta $\mathrm{w}$ art. 5 Konstytucji RP, który expressis verbis stanowi, że ochrona środowiska jest jednym z podstawowych zadań państwa. W przepisie tym zadeklarowano, że: „Rzeczpospolita Polska [...] zapewnia wolności i prawa człowieka i obywatela oraz bezpieczeństwo obywateli, [...] zapewnia ochronę środowiska, kierując się zasadą zrównoważonego rozwoju". Z kolei art. 74 Konstytucji RP odnosi się do obowiązku zapewnienia bezpieczeństwa ekologicznego. Zasada bezpieczeństwa ekologicznego według art. 74 Konstytucji obejmuje działanie lub zaniechanie pozwalające zachować lub przywrócić równowagę przyrodniczą niezbędną do zapewnienia współczesnemu i przyszłym pokoleniom odpowiednich warunków życia oraz realizacji prawa do korzystania z zasobów środowiska i zachowania jego wartości. Bezpieczeństwo ekologiczne współczesnemu i przyszłym pokoleniom ma zapewnić polityka realizowana przez administrację publiczną, a zapewnienie tego bezpieczeństwa stanowi element zrównoważonego rozwoju. Warto dodać, iż w doktrynie zwraca się uwagę, że obywatel ma prawo domagać

${ }^{4}$ Uwzględniane być muszą również inne zasady, zawarte w przepisach aktów stanowiących system prawa ochrony środowiska, jak chociażby zasada zrównoważonego rozwoju (art. 3 pkt 50 p.o.ś.), zasada prewencji (art. 6 ust. 1 i art. 7a p.o.ś.), zasada „zanieczyszczający płaci” (art. 7 p.o.ś.), zasada dostępu do informacji o środowisku (art. 4 i 8 ustawy z dnia 3 października 2008 r. o udostępnianiu informacji o środowisku i jego ochronie, udziale społeczeństwa w ochronie środowiska oraz o ocenach oddziaływania na środowisko, Dz. U. nr 199, poz. 1227 z późn. zm., określanej dalej: u.u.i.ś.), zasada partycypacji publicznej (art. 5 u.u.i.ś.).

5 Jak przykładowo: ustawa z dnia 18 lipca 2001 r. Prawo wodne (tekst. jedn.: Dz. U. z 2012 r., poz. $145 \mathrm{z}$ późn. zm.), ustawa z dnia 16 kwietnia 2004 r. o ochronie przyrody (tekst jedn.: Dz. U. z 2013 r., poz. 627, 628 z późn. zm.). 
się, ażeby władza publiczna w swoich działaniach na rzecz zapewnienia bezpieczeństwa ekologicznego realizowała ideały tzw. dobrej administracji ${ }^{6}$. Postuluje się przyjęcie na gruncie art. 74 Konstytucji $R P$ „obywatelskiego prawa do środowiska", z którego natomiast wprost wywodzi się prawo osobiste?

Artykuł 74 ust. 3 Konstytucji RP gwarantuje każdemu prawo do informacji o stanie środowiska i jego ochronie, a więc o podejmowanych w tej mierze działaniach. Prawo to powinno być jednak rozwijane na szczeblu ustawowym ${ }^{8}$. Ponadto art. 74 ust. 4 Konstytucji przewiduje, że władze publiczne wspierają działania obywateli na rzecz ochrony i poprawy stanu środowiska. Z przepisów Konstytucji wynika, że głównie państwo przyjmuje na siebie obowiązek ochrony środowiska i utrzymania go na odpowiednim poziomie dla zapewnienia możliwości korzystania z niego przez obywateli. Jest to jeden podstawowych celów ogólnospołecznych współczesnego państwa. Artykuł 74 ust. 2 Konstytucji podkreśla, że ochrona środowiska jest obowiązkiem władz publicznych. Z drugiej strony, art. 86 Konstytucji nakłada na każdego obowiązek dbałości o stan środowiska oraz odpowiedzialność za spowodowanie pogorszenia się jego stanu.

\section{Środowisko jako dobro wspólne}

W ustawie - Prawo ochrony środowiska (art. 323) uznano konieczność ochrony środowiska jako dobra wspólnego. Dla realizacji tego założenia ustanowione zostało roszczenie o zaprzestanie bezprawnej działalności powodującej

${ }^{6}$ M. Rudnicki, Ochrona środowiska we współczesnej polityce władz publicznych, [w:] M. Górski, J. Bucińska, M. Niedziółka, R. Stec, D. Strus (red.), Administracja publiczna - człowiek a ochrona środowiska. Zagadnienia społeczno-prawne, Warszawa 2011, s. 303.

7 P. Mazur, Prawo osobiste do korzystania z wartości środowiska naturalnego, „Państwo i Prawo" 1999, z. 11, s. 52.

${ }^{8}$ Aktualnie ma to miejsce w ustawie z 2008 r. o udostępnianiu informacji o środowisku i jego ochronie. Zgodnie z tą ustawą każdemu przysługuje prawo dostępu do informacji o środowisku i jego ochronie. Od osoby ubiegającej się o dostęp do informacji nie wolno żądać wykazania interesu prawnego lub faktycznego. W art. 9 ust. 1 u.u.i.ś. wyliczono rodzaje informacji, które mają charakter „informacji o środowisku”. Są to np.: informacje dotyczące stanu elementów środowiska, informacje o emisjach, informacje dotyczące środków ochrony środowiska, takich jak środki administracyjne, polityki, przepisy prawne dotyczące środowiska, plany, programy oraz porozumienia w sprawie ochrony środowiska itd. Odmowa udostępnienia informacji o środowisku i jego ochronie jest możliwa tylko wówczas, jeżeli ustawa wyraźnie na to pozwala i musi mieć postać decyzji administracyjnej, co umożliwia jej kontrolę, zarówno w postępowaniu odwoławczym, jak i na drodze skargi administracyjnej. W ustawie zawarto także przepisy regulujące zasady udziału społeczeństwa w podejmowaniu rozstrzygnięć związanych z ochroną środowiska, jak prawo składania uwag i wniosków oraz wskazano na szereg uprawnień przysługujących organizacjom ekologicznym.

9 Zob. J. Boć (red.), Konstytucje Rzeczypospolitej oraz komentarz do Konstytucji RP z 1997 roku, Wrocław 1998, s. 134-135. 
zagrożenie lub naruszenie środowiska ${ }^{10}$, z którym może wystąpić Skarb Państwa, jednostki samorządu terytorialnego, a także fundacja lub stowarzyszenie, których podstawowym zadaniem statutowym jest ochrona środowiska. Niezależnie od tego każdy, komu przez bezprawne oddziaływanie na środowisko bezpośrednio zagraża szkoda lub została mu wyrządzona szkoda, może żądać od podmiotu odpowiedzialnego za to zagrożenie lub naruszenie przywrócenia stanu zgodnego $\mathrm{z}$ prawem (np. usunięcie dokonanych zmian w środowisku) i podjęcia środków zapobiegawczych, w szczególności przez zamontowanie instalacji lub urządzeń zabezpieczających przed zagrożeniem lub naruszeniem, a w razie gdy jest to niemożliwe lub nadmiernie utrudnione, może on żądać zaprzestania działalności powodującej to zagrożenie lub naruszenie ${ }^{11}$. Roszczenia oparte na art. 323 p.o.ś. nie przysługują powodowi, jeżeli oddziaływanie na środowisko nie ma cech bezprawności, zwłaszcza gdy jest zgodne z decyzjami administracyjnymi (zezwoleniami, pozwoleniami itp.) określającymi dozwolony zakres korzystania ze środowiska.

Ochronie środowiska jako dobra wspólnego służy także roszczenie o zwrot nakładów poczynionych w związku z naprawieniem szkody w środowisku przez podmiot, który tej szkody nie wyrządził. Wysokość takiego roszczenia ograniczona jest do poniesionych uzasadnionych kosztów przywrócenia stanu poprzedniego.

Należy zauważyć, iż środowisko jako dobro wspólne jest zwrotem przez ustawodawcę niedookreślonym, a tym samym przedmiotem sporów i wątpliwości zgłaszanych w doktrynie ${ }^{12}$. Zdaniem A. Lipińskiego, można przyjąć, że chodzi tu o sytuacje, gdy przedmiotem „szkody” (stanu zagrożenia jej powstaniem) stają się te elementy środowiska, które nie są objęte cywilnymi prawami podmiotowymi (tzw. szkoda ekologiczna). Dodaje on jednak, że ocena ta może być sporna ${ }^{13}$.

K. Gruszecki w przepisie art. 323 p.o.ś. dostrzega podobieństwo do actio popularis. Zauważa, że w indywidualnym przypadku każdy z podmiotów legitymowanych do wystąpienia z roszczeniem powinien mieć świadomość, czy występuje we własnym interesie, czy też jako „rzecznik interesu publicznego" ${ }^{14}$. Należy zaznaczyć, iż powoływany przepis nie wprowadza co prawda actio popularis (czyli uprawnienia do dochodzenia roszczeń przed sądem $w$ interesie publicznym przez każdego obywatela), ale pozwala na występowanie w interesie publicznym (interesie środowiska) przez podmioty niedotknięte bezpośrednio szkodą ${ }^{15}$.

${ }^{10}$ Zob. art. 323 ust. 2 p.o.ś. Powodowi nie służą jakiekolwiek roszczenia pieniężne.

11 Zob. art. 323 ust. 1 p.o.ś.

12 A. Jaworowicz-Rudolf, Odpowiedzialność administracji publicznej za stan środowiska, [w:] Z. Duniewska, M. Stahl (red.), Odpowiedzialność administracji i w administracji, Warszawa 2013, s. 582-583.

${ }_{13}$ A. Lipiński, [w:] J. Jendrośka (red.), Ustawa z dnia 27 kwietnia 2001 r. Prawo ochrony środowiska. Komentarz, Wrocław 2001, s. 811.

14 Zob. K. Gruszecki, Prawo ochrony środowiska. Komentarz, Warszawa 2008, s. 567.

15 Zob. W. Radecki, [w:] M. Górski, M. Pchałek, W. Radecki i in, Prawo ochrony środowiska. Komentarz, Warszawa 2011, s. 1117. 
B. Rakoczy sugeruje, że dobro wspólne oznacza, że ochrona podejmowana jest ze względu na interes publiczny, a nie prywatny, i zakłada istnienie sytuacji, gdy zagrożone jest dobro ogółu, a nie jednostki. Chodzi więc o takie naruszenie stanu środowiska, które powoduje szersze oddziaływanie niż tylko zagrożenie praw jednostki ${ }^{16}$. Zastosowanie art. 323 ust. 2 p.o.ś. wymaga każdoczesnej analizy, czy rzeczywiście przesłanka zagrożenia lub naruszenia środowiska jako dobra wspólnego wystąpiła, a kryterium dobra wspólnego jest ogólne i ocenne ${ }^{17}$. Moim zdaniem pogląd, że dobro wspólne w rozumieniu art. 323 p.o.ś. trzeba utożsamiać $\mathrm{z}$ ochroną interesu publicznego należy w pełni podzielić.

W. Radecki słusznie zauważa, że przy rozstrzyganiu, czy zaistniała szkoda dotyczy środowiska jako dobra wspólnego decydującego znaczenia nie ma określenie właściciela terenu, za „dobro wspólne” można uznać teren (fragment środowiska), który stanowi własność podmiotu prywatnego (osoby fizycznej czy prawnej). Dobro ogółu może być narażone także wtedy, gdy szkoda powstała na terenie prywatnym, należy zatem przyjąć, że także szkody wyrządzone na terenie prywatnym mogą być szkodami w środowisku traktowanym jako dobro wspólne. Autor ten zaznacza, że gdyby przyjąć pogląd, że decydujące znaczenie ma tu to, do kogo należy dany teren, to można by dojść do dość absurdalnych konkluzji - gdybyśmy założyli, że dobrem wspólnym są tylko elementy środowiska znajdujące się na terenie należącym do Skarbu Państwa czy jednostki samorządu terytorialnego, a te położone na terenie prywatnym już nie, to jak należałoby traktować nieruchomości należące np. do spółek komunalnych, spółek Skarbu Państwa, czy spółek z udziałem i Skarbu Państwa, i podmiotów prywatnych? ${ }^{18}$

Warto też zasygnalizować, że w ustawach odnoszących się do ochrony środowiska pojęcie ,środowiska jako dobra wspólnego” jest użyte przez prawodawcę także w art. 24 ust. 2 ustawy z dnia 13 kwietnia 2007 r. o zapobieganiu szkodom w środowisku i ich naprawie ${ }^{19}$, art. 100a ust. 2 ustawy z dnia 29 listopada $2000 \mathrm{r}$. Prawo atomowe $e^{20}$, art. 57 ust. 2 ustawy z dnia 22 czerwca 2001 r. o organizmach genetycznie zmodyfikowanych ${ }^{21}$.

W. Radecki przypomina, że za punkt wyjścia kwalifikacji środowiska jako dobra wspólnego można przyjąć nieobowiązujący już od dawna przepis art. 12 ust. 2 Konstytucji PRL z 1952 r. w brzmieniu nadanym jej nowelą z 10 lutego 1976 r., który w redakcji tekstu jednolitego z 1976 r. stanowił: „Polska Rzeczpospolita

${ }^{16}$ Zob. B. Rakoczy, [w:] J. Ciechanowicz-McLean, Z. Bukowski, B. Rakoczy, Prawo ochrony środowiska. Komentarz, Warszawa 2008, s. 515.

17 Zob. B. Rakoczy, Skarb Państwa i jednostki samorzadu terytorialnego jako powodowie w sprawach z zakresu ochrony środowiska, [w:] J. Ciechanowicz-McLean (red.), Prawne aspekty interwencjonizmu w gospodarce i środowisku, „Gdańskie Studia Prawnicze” 2009, t. 22, s. 208.

18 W. Radecki, [w:] M. Górski, M. Pchałek, W. Radecki i in., op. cit., s. 1118.

19 Dz. U. nr 75, poz. 493 z późn. zm.

20 Tekst jedn.: Dz. U. z 2012 r., poz. 264 z późn. zm.

${ }^{21}$ Tekst jedn.: Dz. U. z 2007 r. nr 36, poz. 233 z późn. zm. 
Ludowa zapewnia ochronę i racjonalne kształtowanie środowiska naturalnego, stanowiącego dobro ogólnonarodowe". W przepisie tym nie było wprawdzie mowy o dobru wspólnym, lecz tylko o dobru ogólnonarodowym, ale było to uzasadnione ówczesnymi uwarunkowaniami ustrojowymi. Zdaniem W. Radeckiego, nie było wątpliwości, że w przepisie tym wyrażono zadanie państwa, a w istocie obligatoryjny wzór działania adresatów Konstytucji, a więc przede wszystkim organów władzy i administracji państwowej. Oznaczał ciążący na organach ustawodawczych obowiązek wydawania ustaw niezbędnych do realizacji ochrony środowiska, a na organach wykonawczych obowiązek wydawania przepisów konkretyzujących postanowienia ustawy zasadniczej, a także uwzględniania wymagań ochrony i racjonalnego kształtowania środowiska w toku bieżącego kierowania, zwłaszcza procesami gospodarczymi ${ }^{22}$.

M. Rudnicki podkreśla, że środowisko rozumiane jako dobro wspólne nie powinno być postrzegane jako własność jednostek, ale powinno być traktowane jako dobro wspólne stanowiące „funkcje tych wszystkich warunków, które zapewniają ludziom w społeczeństwie życie godne człowieka". Społeczeństwo ma naturalne prawo domagania się od jednostek zachowań realizujących ideał zachowania dobra wspólnego, a także samo jest adresatem postulatów jednostek ${ }^{23}$.

\section{Rola administracji publicznej w zakresie ochrony środowiska}

$\mathrm{Na}$ gruncie ustawodawstwa zwykłego środowisko jest chronione instrumentami zaliczanymi do różnych gałęzi prawa, jak prawo cywilne czy karne ${ }^{24}$, jednakże szczególną rolę w prawnej ochronie odgrywają instrumenty administracyjnoprawne. Skoro bowiem przyjmujemy, że ochrona środowiska jest zadaniem państwa, to jest ono wypełniane przez aparat państwowy - głównie organy administracji, gdyż większość zadań państwa w tej dziedzinie ma charakter zadań z zakresu administracji publicznej. Trzeba jednak zaznaczyć, że dla aparatu państwowego ochrona środowiska powinna być nie tylko konkretnymi zadaniami do wykonania ${ }^{25}$, mającymi charakter interdyscyplinarny i wieloaspektowy, ale

22 W. Radecki, Ustawa o zapobieganiu szkodom w środowisku i ich ochronie. Komentarz, Warszawa 2007, s. 104.

${ }^{23}$ M. Rudnicki, op. cit., s. 302.

${ }^{24}$ Zob. np. rozdział XXII k.k. z 1997 r. - Przestepstwa przeciwko środowisku. Zob. także: W. Radecki, Odpowiedzialność za wykroczenia jako środek prawny ochrony środowiska, [w:] M. Pchałek, B. Rakoczy (red.), Wybrane problemy prawa ochrony środowiska, Warszawa 2010, s. $297-314$.

${ }_{25}$ Zob. szerzej nt. klasyfikacji zadań administracji publicznej w dziedzinie ochrony środowiska: M. Górski (red.), op. cit., s. 81-98. Por. A. Barczak, Zadania organów administracji w zakresie ochrony środowiska, [w:] P. Korzeniowski (red.), Prawa i obowiązki przedsiębiorców w ochronie środowiska, Warszawa 2010, s. 65-71. 
również pewną wytyczną działania, kryterium oceny prawidłowości (z ogólnospołecznego punktu widzenia) wszelkich podejmowanych i realizowanych zamierzeń.

Ochrona środowiska jako dobra wspólnego w ramach interesu publicznego należy przede wszystkim do organów administracji publicznej, wykorzystujących władcze metody, a w szczególności nakładających sankcje administracyjne $\mathrm{w}$ formie decyzji, egzekwujących w swoistej dla administracji procedurze odpowiedzialność za zdarzenia, działania lub zaniechania podlegające ujemnej kwalifikacji normatywnej, tj. naruszające wymagania ochrony środowiska. Dwoma podstawowymi zadaniami organów administracji publicznej w ochronie środowiska są czuwanie nad wykorzystywaniem środowiska bez naruszania go jako dobra wspólnego, a więc bez naruszania interesu publicznego, jak i reagowanie na sytuacje, gdy doszło do naruszenia środowiska jako dobra wspólnego w ramach ochrony interesu publicznego, z uwzględnieniem instrumentów prawnych dotyczących odpowiedzialności prawnej, w tym administracyjnej ${ }^{26}$.

Roli administracji publicznej $\mathrm{w}$ zakresie ochrony środowiska nie można jednak sprowadzać jedynie do ustalania i egzekwowania odpowiedzialności za szkody środowiskowe, pełniących zadania prewencji ogólnej i szczególnej, oraz do kontroli stanu środowiska. Administracja publiczna w dziedzinie ochrony środowiska musi podejmować także wiele innych działań, wynikających między innymi z polityki ekologicznej państwa. Warto chociażby zasygnalizować, iż jednym z filarów Polityki Ekologicznej Państwa w latach 2009-2012 z perspektywa do roku $2016^{27}$ jest uspołecznianie polityki ekologicznej m.in. poprzez zapewnienie udziału pozarządowych organizacji ekologicznych we wszystkich gremiach podejmujących decyzje dotyczące ochrony środowiska, intensyfikację edukacji ekologicznej, itd. Warto zaznaczyć, że ustawa Prawo ochrony środowiska zobowiązuje wszystkie jednostki samorządu terytorialnego do sporządzenia programów ochrony środowiska ${ }^{28}$, będących doprecyzowaniem polityki ekologicznej państwa. Nie wyklucza to oczywiście wprowadzania przez administrację samorządową do programów lokalnych problemów terenowych.

${ }^{26}$ A. Jaworowicz-Rudolf, Funkcje sankcji administracyjnych $w$ ochronie środowiska, [w:] M. Stahl, R. Lewicka, M. Lewicki (red.), Sankcje administracyjne. Blaski i cienie, Warszawa 2011, s. 241.

27 Uchwała Sejmu Rzeczypospolitej Polskiej z dnia 22 maja 2009 r. w sprawie przyjęcia dokumentu Polityka ekologiczna Państwa w latach 2009-2012 z perspektywa do roku 2016 („Monitor Polski” 2009, nr 34 poz. 501).

${ }^{28}$ Zgodnie z treścią art. 17 ustawy Prawo ochrony środowiska w celu realizacji polityki ekologicznej państwa organ wykonawczy województwa, powiatu i gminy, sporządza odpowiednio wojewódzkie, powiatowe i gminne programy ochrony środowiska. Organ sporządzający właściwy program w postępowaniu, którego przedmiotem jest sporządzenie programu ochrony środowiska zapewnia możliwość udziału społeczeństwa, na zasadach i w trybie określonych w ustawie o dostępie do informacji o środowisku. 
Katalog zadań administracji publicznej w zakresie ochrony środowiska ma charakter płynny - musi się zmieniać w zależności od sytuacji ekonomicznej, ekologicznej i politycznej. Wydaje się, że jednym z istotniejszych kierunków swoiście pojmowanego ,interwencjonizmu państwowego" podyktowanego względami ochrony środowiska powinno być oddziaływanie na podmioty gospodarujące, głównie za pośrednictwem instrumentów ekonomicznych (np. preferencji podatkowych, kredytowych), w celu preferowania przedsięwzięć proekologicznych - tzn. czystych i oszczędnych ekologicznie oraz o charakterze rekultywacyjnym. Administracja publiczna powinna także sama podejmować konkretne przedsięwzięcia ochronne, m.in. w zakresie monitoringu środowiska, ochrony konserwatorskiej (określonych obiektów i terenów), budowy czy tez modernizacji infrastruktury technicznej, finansować działania o charakterze rekultywacyjnym, wspierać działania naukowo-badawcze, co jednak w sposób oczywisty związane jest $\mathrm{z}$ dysponowaniem niezbędnymi środkami finansowymi na te cele ${ }^{29}$.

Jednym $\mathrm{z}$ kluczowych zadań państwa $\mathrm{w}$ dziedzinie ochrony środowiska, wykonywanym za pośrednictwem administracji publicznej powinno być także kształtowanie odpowiedniego poziomu „świadomości ekologicznej” społeczeństwa, miedzy innymi poprzez wspieranie działalności organizacji społecznych w tej dziedzinie, finansowanie edukacji ekologicznej (np. upowszechnianie jej w środkach masowego przekazu), organizowanie akcji edukacyjnych o profilu proekologicznym dla najmłodszych, wystaw, happeningów, rodzinnych pikników itd. Właściwy poziom świadomości ekologicznej społeczeństwa pozwala na łatwiejsze wprowadzanie przez administrację niezbędnych działań pro środowiskowych. Jak już jednak podkreślałam, podstawowe znaczenie dla szerokiego, społecznego udziału w urzeczywistnianiu celów ekologicznych ma nie tylko odpowiednia edukacja ekologiczna, ale też zapewnienie powszechnego dostępu do informacji o środowisku ${ }^{30}$. Warto też zauważyć, iż w sprawach szeroko rozumianej ochrony środowiska istnieje różnorodność form i możliwości współdziałania administracji ${ }^{31}$, które należy wykorzystywać. Skoro przyjmujemy, że środowisko jest dobrem wspólnym, to przeszkodą współdziałania w sprawach środowiskowych nie powinna być uwypuklana samodzielność podmiotowa, a tym bardziej względy polityczne.

\section{Podsumowanie}

Zagadnienia ochrony środowiska są wszechobecne we współczesnym świecie i ich krąg się wciąż rozszerza, a w konsekwencji wzrasta liczba regulacji prawnych. Obejmują one m.in. ochronę wód, lasów, klimatu, bioróżnorodności,

29 A. Jaworowicz-Rudolf, Odpowiedzialność administracji..., s. 584-585.

${ }^{30}$ Por. M. Rudnicki, op. cit., s. 305.

31 Zob. szerzej: A. Jaworowicz-Rudolf, Formy współdziałania administracji samorzadowej w sprawach z zakresu ochrony środowiska, [w:] K. Miśtal (red.), Współdziałanie w samorządzie terytorialnym, Łódź 2012, s. 15-26. 
ochrony przed odpadami, organizmami genetycznie modyfikowanymi itd. Regulacjom prawnym podlegają coraz to bardziej szczegółowe kwestie, a dodatkowo nowo powstałe przepisy są nieustannie nowelizowane. Co istotne, problemy ochrony środowiska mają charakter interdyscyplinarny, a prawo jest jednym z instrumentów ochrony środowiska, przy czym szczególna rola przypada tu normom administracyjnoprawnym. Prawo to niestety nie jest najlepszej jakości, jest nieprecyzyjne, rodzi szereg wątpliwości interpretacyjnych. Można nawet zaryzykować twierdzenie, że dla przeciętnego obywatela prawo dotyczące ochrony środowiska jest absolutnie niezrozumiałe. Jest to konsekwencją znacznej intensyfikacji unormowań, operowania w przepisach pojęciami właściwymi dla nauk przyrodniczych, technicznych, chemicznych itd. Wynika to też m.in. z niedookreśloności pojęć normatywnych dotyczących środowiska oraz nieadekwatności metod regulacji prawnej do przedmiotu ochrony, jakim jest środowisko. 